\title{
Animal Trypanosomiasis in Cattle of Good Body Condition Score in the Adamawa Region of Cameroon: Hematological and Immunological Implications
}

\author{
Ebanga Echi Joan ${ }^{1}$, Amadoh Jude Akumbu ${ }^{1}$, Farikou Oumarou ${ }^{2,3}$, Abba Samuel $^{\beta}$ and Oumar Mahamat ${ }^{1^{*}}$
}

${ }^{1}$ Department of Biological Sciences, Faculty of Science, University of Bamenda, Cameroon

${ }^{2}$ Faculty of Health Sciences, University of Bamenda, Cameroon

${ }^{3}$ Mission Special d'Eradication des Glossines (MSEG), Ngaoundere, Cameroon

*Corresponding author: Oumar Mahamat, Department of Biological Sciences, Faculty of Science, University of Bamenda, Bambili, PO Box 39, Cameroon, Tel: 00237-676569718

\begin{abstract}
The control of animal trypanosomiasis consists, amongst other things, the punctual treatment of new cases, primarily diagnosed by pastoralists on the basis of clinical signs. This practice suggests that many healthy infected animals are left untreated. In this study, animal trypanosomiasis in cattle of good body condition score was evaluated, the existence of polyclonal anti-trypanosome (Anti-tryps) and its serotherapy implications were discussed. From January to March 2020, the study was carried out in the Mission Special d'Eradication des Glossines in Ngaoundere. A total of 298 blood samples were collected from cattle in randomly selected ranches in Ngaoundere. The blood samples were subjected to parasitological examination using the buffy coat method and the packed cell volume determined. A serum sample of cattle with trypanosome was subjected to serotherapeutical study against Trypanosoma congolense in mice and the parasitemia and mortality were analyzed. An overall trypanosomiasis prevalence of $4.02 \%$ was found in the cattle examined. Trypanosome-infected cattle had significantly $(P=0.0001)$ lower Packed Cell Volumes (PCV). Anemia was highly associated with trypanosome infection $(O R=10.54 ; p=0.0005)$. Species of trypanosomes identified were Trypanosoma congolense and Trypanosoma vivax. Concentration of $5 \mu \mathrm{l} / \mathrm{g}$ body weight of antiserum showed significantly $(P=0.02)$ protective effect in cure and passive immunization of mice. In conclusion, carriers of trypanosomes are present amongst cattle of good body condition score. Attempts to successfully reduce the population of reservoir of trypanosomes within herds and control the disease will need to consider mass screening including both animals of good and poor body conditions and anti-sera of trypanosomes will be a good candidate for therapeutical and preventive control.
\end{abstract}

\section{Keywords}

Animal trypanosomiasis, Cattle, Body condition score, Prevalence, Haematology, Immunology

\section{Introduction}

\section{Background}

Livestock production in Cameroon, like in many other areas in Africa, is impeded by the presence of tsetse fly [1] which cyclically transmits animal trypanosomosis [2]. Trypanosomosis is a cause of abortion, premature births, prenatal losses, infertility in males through testicular damage, the reduction of milk production in diary animals and increased spending on drugs. The diseases, therefore, contributes to the poverty of pastoralists. Alone, trypanosomosis was considered to be responsible for one quarter of economic losses due to animal pathologies [3].

In practice, the body condition scoring (BCS) constitutes one of the major criteria used for distinguishing differences in nutritional needs of beef cows in the herd [4]. It is also used to as a clinical sign of infection as most infected animals tend to emaciate and have a poor body condition score. However, having a good BCS is not synomous to the absence of parasites. In contrast, it can constitute a carrier for the infectious agents increasing the endemicity of the infection.

In Cameroon, despite the use of trypanocides, spo-

Citation: Joan EE, Akumbu AJ, Oumarou F, Samuel A, Mahamat O (2020) Animal Trypanosomiasis in Cattle of Good Body Condition Score in the Adamawa Region of Cameroon: Hematological and Immunological Implications. Int J Trop Dis 3:041. doi.org/10.23937/2643-461X/1710041

Accepted: December 21, 2020; Published: December 23, 2020

Copyright: (C) 2020 Joan EE, et al. This is an open-access article distributed under the terms of the Creative Commons Attribution License, which permits unrestricted use, distribution, and reproduction in any medium, provided the original author and source are credited. 
radic cases of trypanosomiasis are generally diagnosed by herdsmen on the basis of clinical signs solely [3]. This situation demonstrates that many apparently healthy (those of good body condition score) but infected animals are not treated. This selection may be the cause of the persistence of the disease.

Thus, in this study we examined the prevalence and parasite species of animal trypanosomosis in zebu cattle of good body condition score, examine the hematological effect and establish the presence of antibodies in these animals which protect them from clinical sign of illness.

\section{Materials and Methods}

\section{Ethical consideration}

Permission was granted by the Department of Biological Sciences of The University of Bamenda to carry out this study in Ngaoundere. Authorization was granted by the Regional Delegation of Animal and Life Stock Adamawa (No 013/L/MINEPIA/MSEG) to conduct the research. A verbal consent was obtained from the herders and cattle owners, with care taken in blood collection in order not to harm the animals.

\section{Study design}

A cross sectional survey was used to study the prevalence of cattle in the field. In this design, ranches were selected at random and in each ranch, purposive selection was used to select cattle of good body condition score to study the prevalence. Blood was collected from selected cattle in the various ranches. The body condition of animal were monitored based on their physical appearance [5] and categorized as follows: BCS Category: Poor: $\leq 3$; Good: $>3$ and < 7; and Very good: $\geq$ 7 [6]. In the laboratory, an experimental study design was used in which mice were infected with Trypanosoma parasites and the effects of anti tryps serum against trypanosomes examined.

\section{Study area}

This study was carried out in Ngaoundere in the Adamawa region of Cameroon. All experiments were carried out in a research laboratory referred to as Mission Special d'Eradication des Glossines (MSEG) of the Regional Delegation of Animal and Life Stock Ngaoundere, Adamawa region. This laboratory is in charge of eradication of Tsetse flies and animal trypanosomiasis in the region.

\section{Mice}

Adult out-bred albino mice weighing 18-21g reared at the animal house of the Laboratory of LANAVET (National Veterinary Laboratory) Garoua, were used. The animals were housed in a fly proof laboratory animal house and given pelleted chick grower feed and water ad libitum. The feed was mixed with water and rolled into small balls then kept in a dry bowl where it dehydrated and became hard. After one day interval, each group was given a ball of food. Water was given to the animals using $350 \mathrm{~mL}$ plastic bottle with hole and tube in the lid. Animals used were in compliance with the ethical procedures of the Animal Use and Care Committee, National Institutes of Health (NIH) guidelines [7].

\section{Blood collection}

Various bloods were collected from the jugular vein of animals into Ethylene Diamine Tetraacetic acid (EDTA) tubes. While in the field, samples were kept in a cool box with ice packs and transported to the laboratory immediately after collection for parasitological and haematological analyses.

\section{Preparation of polyclonal anti-trypanosome se- rum}

Blood samples of infected and uninfected animal were collected in dry tubes. The blood was left at room temperature $\left(20-25^{\circ} \mathrm{C}\right)$ in $10-\mathrm{mL}$ glass tubes for $1 \mathrm{~h}$ to induce clot formation and then centrifuged at $1800 \mathrm{rpm}$ for 10 minutes to obtain the serum and stored at $-80^{\circ} \mathrm{C}$ until usage. Polyclonal Anti-Trypanosoma (Anti-Tryps) serum used in this study was obtained from cattle having both Trypanosoma vivax and Trypanosoma congolense. Blood from Trypanosoma free cattle was used to obtain serum without antibodies. They were confirmed using rapid diagnostic test (VerYDiag, France).

\section{Preparation of parasite}

Trypanosoma parasites used for this study, were directly isolated from a clinically sick cattle and identified following a procedure described by Murray, et al. [8]. The observed parasites were identified by matching the observed parasite with the structure on a figure cited by Desquesnes M [9].

\section{Epidemiological and hematological survey}

Bovine trypanosomiasis survey: The parasitological diagnosis was based on the methodology described by Mamoudou, et al. [2]. The parasites were seen exhibiting lashy movement with their flagellum [10]. Trypanosome species were identified by comparing the observed trypanosomes under the microscope to a figure used by Desquesnes M [9].

Haematological survey: Capillary tubes were filled with blood. The tubes were sealed at one end and placed on a haematocrit centrifuge. The tubes were centrifuged at $10.000 \mathrm{~g}$ per $5 \mathrm{~min}$. The Packed Cell Volume (PCV) was measured using Hawksley microhaematocrit scale and recorded [11]. Animals with PCV value below $24 \%$ were considered to be anaemic [8].

\section{Immunological survey in mice}

Passive immunization against $T$. congolense: Twenty four mice were grouped into 4 groups of 6 animals 
each. After grouping, mice were immunosuppressed by injection with $2.5 \mathrm{mg} / \mathrm{kg}$ bw cortisone (an immunosuppressive drug). Two groups were injected intra-peritoneally with 2.5 and $5 \mu \mathrm{l} / \mathrm{g}$ bw of Anti-Tryps respectively. One was injected with $5 \mu \mathrm{l} / \mathrm{g}$ bw of normal serum (NRS) as negative control and the last group received a standard drug (dimenazene aceturate, $10 \mathrm{mg} / \mathrm{kg}$ bw) [12], taken as positive control. Animals were treated at 1-day intervals four times (Days 1, 3, 5 and 7) and intraperitoneally (ip) infected with $T$. congolense $(0.1 \mathrm{ml}$ of 80 parasites/ml suspension) on day 9 . Animals were kept for 8 days, the number of survival animal was recorded every days and blood was collected from the tail of survival animals on day 4 to analyse the parasitemia by light microscopy.

Curative ability against $T$. congolense: Twenty-four mice were group in four groups of six mice each then immunosuppressed by injection with $2.5 \mathrm{mg} / \mathrm{kg}$ bw cortisone. Two groups were chosen for treatment with 2.5 and $5 \mu \mathrm{l} / \mathrm{g}$ bw of anti-tryps respectively. One group was injected with $5 \mu \mathrm{l} / \mathrm{g}$ bw of normal serum (NRS) as negative control and the last group to receive $10 \mathrm{mg} /$ $\mathrm{kg}$ bw of dimenazene aceturate [12], as positive control. On day 1 of experiment, animals were intraperitoneally (ip) infected with $T$. congolense $(0.1 \mathrm{ml}$ of 80 parasites/ $\mathrm{ml}$ suspension) and animals were daily treated three times (Days 2, 3 and 4). Animals were kept for 8 days, the number of survival animal was recorded every day. Blood was collected from the tail of survival animals on day 4 to analyse the parasitemia by light microscopy.

\section{Determination of trypanosome infection in mice}

Parasitaemia in all of the mice was monitored by microscopic examination of wet preparation from tail blood except in cases where death occurred before the expiration of the period [13]. Briefly, 100 microscope fields of wet films were examined using a light microscope at $40 \mathrm{X}$ magnification. The parasitemia was expressed as number of parasites/ml of blood.

\section{Statistical analysis}

Experimental values were expressed as the mean \pm standard deviation of three experiments in triplicate. Chi-square and $Z$ tests were used to compare the prevalence of trypanosome infections in the animals and trypanosomes species. The mean PCV and BCS of trypanosome infected and uninfected cattle were compared by Student's t-test. Levels of $p<0.05$ were considered as indicative of significance. All calculations were carried out using the GraphPad Prism ${ }^{\circledR}$ V5.03 software (GraphPad Software Inc. ${ }^{\circledR}, \mathrm{CA}$, USA).

\section{Results}

\section{Trypanosomes species and prevalence in cattle in good body condition score}

Of the 298 animals examined, 12 (4.02\%) were infected with trypanosomes. Two species of trypanosomes were identified. 8 cattle were infected with $T$. congolense only with prevalence of $2.68 \%$ while 4 cattle were infected with both $T$. congolense and $T$. vivax (Table 1).

\section{Effect of body condition score on the infectivity of different trypanosome species in cattle}

The result showed that out of the 8 animals with $T$. congolense only, majority (75\%) were in BCS 2 . In the case of mixed infection with $T$. congolense and $T$. vivax all the positive 4 animals were of BCS 2 (Table 2).

\section{Effect of trypanosome' species on PCV in cattle}

The results of hematocrit score in cattle infected by T. congolense and T. vivax are shown in Figure 1. Cattle infected with trypanosomes had a high mean PCV compared to that for cattle not infected with trypanosomes. PCV of uninfected animals $(27.14 \pm 6.03)$ was statistically significant as compared to cattle infected with $T$. congolense $(19.14 \pm 2.68 ; \mathrm{P}=0.0001)$ as well as compared to those infected with $T$. vivax $(17.5 \pm 0.57$; $\mathrm{P}=0.0016)$. The mean PCV of cattle infected with $T$. congolense and $T$. vivax showed no significant statistical difference $(P=0.25)$.

\section{Association of trypanosome infection with anae- mia in cattle of good boy condition score}

A total of 102 cattle were anaemic against 196 non anaemic. The prevalence of anaemia trypanosome-infected cattle was $83.33 \%$ (10) and $16.67 \%$ (2) without anaemia (OR: 10.54; 95\% Cl: 2.26-49.11). Anaemia was

Table 1: Parasite species and prevalence in cattle.

\begin{tabular}{|l|l|l|}
\hline Parasites species & No. Positive & Prevalence (\%) \\
\hline Total & 12 & 4.02 \\
\hline T. congolense only & 8 & 2.68 \\
\hline $\begin{array}{l}\text { T. vivax and } T . \\
\text { congolense }\end{array}$ & 4 & 1.34 \\
\hline
\end{tabular}

No significant $(P>0.05)$.

Table 2: Trypanosoma' prevalence related to body condition score in cattle.

\begin{tabular}{|l|l|l|l|l|}
\hline Parasites species & No. cattle & \multicolumn{3}{|l|}{ Body condition score } \\
\cline { 2 - 4 } & & $\mathbf{1}$ & $\mathbf{2}$ & $\mathbf{3}$ \\
\hline T. congolense & 8 & - & $75(6)$ & $25(2)$ \\
\hline T. vivax and T. congolense & 4 & - & $100(4)$ & - \\
\hline No parasite & 286 & - & $87.76(251)$ & $12.24(35)$ \\
\hline
\end{tabular}

No significant $(P>0.05)$. 


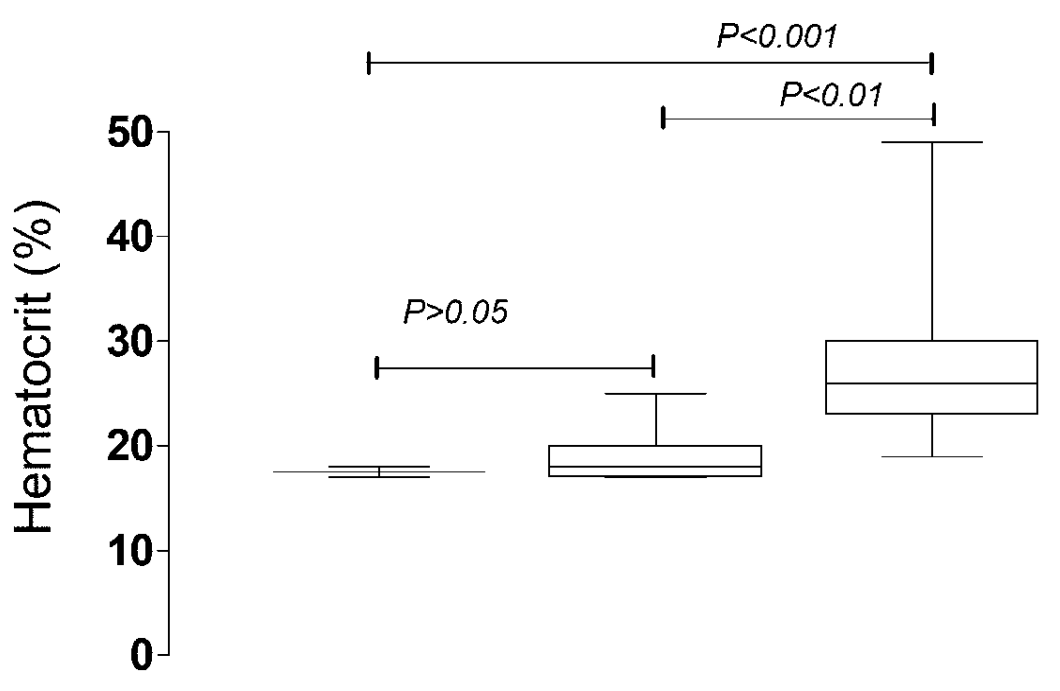

\section{$T$. vivax $T$. congalense No parasite}

\section{Parasite' species}

Figure 1: Hematocrit level of cattle with respect to Trypanosome species.

Table 3: Prevalence of anaemia in cattle with and without trypanosome together with results of univariate logistic regression analyses.

\begin{tabular}{|l|l|l|l|l|l|}
\hline & A. positive & Mean (SD) & Prevalence (\%) & OR (95\% Cl) $^{\mathbf{a}}$ & $\boldsymbol{P}^{\text {-value }}$ \\
\hline Total & 102 & $21(1.6)$ & 34.22 & & $10.54(2.26-9.11)$ \\
\hline Infected Cattle & 10 & $18.4(1.14)$ & 83.33 & 0.0005 \\
\hline Uninfected Cattle & 92 & $21.28(1.37)$ & 32.16 & & \\
\hline
\end{tabular}

a OR: odds ratio; $\mathrm{Cl}$ : Confidence Interval

* A. positive: Anemia positive

Table 4: Behavior of $T$. congolense infected mice after in curative treatment with anti- tryps polyclonal serum free anti-tryps serum and diminazene aceturate.

\begin{tabular}{|c|c|c|c|c|c|}
\hline \multicolumn{4}{|c|}{ Anti-tryps polyclonal serum ( $\mu \mathrm{l} / \mathrm{g}$ bw) } & \multirow{2}{*}{$\begin{array}{l}\text { Free Anti-tryps serum } \\
(5 \mu \mathrm{l} / \mathrm{g} \text { bw) }\end{array}$} & \multirow[t]{2}{*}{ Drug (10 mg/kg bw) } \\
\hline & 5 & & 2.5 & & \\
\hline Day 1 & & $\begin{array}{ll}\text { - } & 6 \text { alive } \\
\text { - } & \text { Weak } \\
\text { - } & \text { eating }\end{array}$ & $\begin{array}{ll}\text { - } & 6 \text { alive } \\
\text { - } & \text { Weak } \\
\text { - } & \text { eating }\end{array}$ & $\begin{array}{ll}\text { - } & 6 \text { alive } \\
\text { - } & \text { Weak } \\
\text { - } & \text { eating }\end{array}$ & $\begin{array}{ll}\text { - } & 6 \text { alive } \\
\text { - } & \text { Weak } \\
\text { - } & \text { eating }\end{array}$ \\
\hline Day 2 & & $\begin{array}{ll}\text { - } & 4 \text { alive } \\
\text { - } & \text { All weak } \\
\text { - } & 2 \text { are eating }\end{array}$ & $\begin{array}{ll}\text { - } & 5 \text { alive } \\
\text { - } & \text { All weak } \\
\text { - } & 2 \text { are eating }\end{array}$ & $\begin{array}{ll}\text { - } & 5 \text { alive } \\
\text { - } & \text { All weak } \\
\text { - } & 1 \text { is eating }\end{array}$ & $\begin{array}{ll}\text { - } & 6 \text { alive } \\
\text { - } & \text { All weak } \\
\text { - } & \text { All are eating }\end{array}$ \\
\hline Day 3 & & $\begin{array}{l}\text { - } 3 \text { alive } \\
\text { - } \quad \text { All weak }\end{array}$ & $\begin{array}{ll}\text { - } & 2 \text { alive } \\
\text { - } & \text { All weak } \\
\text { - } & \text { No eating }\end{array}$ & All dead & $\begin{array}{ll}\text { - } & 5 \text { alive } \\
\text { - } & \text { All active } \\
\text { - } & \text { All eating }\end{array}$ \\
\hline & - & No eating & & & \\
\hline Day 4 & - & All dead & $\begin{array}{l}\text { - } 1 \text { alive } \\
-\quad \text { No moving }\end{array}$ & - & $\begin{array}{ll}\text { - } & 4 \text { alive } \\
\text { - } & \text { All active } \\
\text { - } & \text { All eating }\end{array}$ \\
\hline Day 5 & - & & All dead & - & $\begin{array}{ll}- & 4 \text { alive } \\
- & \text { All active } \\
- & \text { All eating }\end{array}$ \\
\hline Day 8 & - & & - & - & $\begin{array}{l}\text { - } 2 \text { alive } \\
\text { - Weak }\end{array}$ \\
\hline
\end{tabular}

NS $=$ Normal serum; Drug $=$ Diminazene aceturate 
significantly associated with infection in cattle in a good BCS $(P=0.0005)$ (Table 3).

\section{Clinical changes of mice in curative treatment}

After animals were infected with $T$. congolense, behavior changes were observed in the various groups ( $\mathrm{Ta}$ ble 4). The animals that received the anti-trypanosomes serum looked healthier compared to the group which received serum without antibodies a few days post infection. Three days post infection, most of the animals that received the anti-tryps serum were still eating and looked healthier compared to those that received the free anti-tryps serum. The animals in the group that received the standard drug (diminazene aceturate, 10 $\mathrm{mg} / \mathrm{kg}$ body weight) were the strongest and healthiest group of animals compared to the other groups that received the anti-Tryps serum and free anti-tryps serum. The positive control group animals also ate considerably higher compared to all other groups.

Clearance of $T$. congolense by anti-tryps polyclonal serum in mice

All the animals that received the anti-tryps-free serum were dead before the day of examination. The parasitaemia of survival animal recorded in anti-tryps-treated mice and those that received the diminazene aceturate are indicated in Table 5. Compared to the diminazene aceturate, the average number of parasite per $\mathrm{ml}$ of blood was significantly higher in the groups of animal which received the anti-tryps polyclonal serum $(P=0.01)$.

\section{Curative effect of anti- tryps serum on $T$. congo- lense infection on the survival of mice}

The trend of survival of animals is shown in Figure 2. The animals in the negative control group all died by day 3 after infection, while those that received anti-tryps polyclonal serum survived. Compared to anti-tryps polyclonal serum, animals receiving diminazene aceturate lived longer.

Effect of passive immunization with anti-tryps polyclonal serum in infectivity of $T$. congolense infection on mice

Clinical changes of mice in passive immunisation treatment: Table 6 shows the general behavior of mice

Table 5: Parasitemia of $T$. congolense isolates during the experimental infection in mice.

\begin{tabular}{|l|l|l|l|}
\hline Treatment & Number of mice tested & Number of animal resistant & $\begin{array}{l}\text { Average parasitemia } \\
\text { (Parasites/ml blood) }\end{array}$ \\
\hline Normal serum & 6 & 0 & - \\
\hline Reference drug & 6 & 5 & $8 \pm 10.95$ \\
\hline Anti-Tryps serum $(\mu \mathrm{l} / \mathrm{g} \mathrm{bw})$ & & $40 \pm 0^{\star a}$ \\
\hline 2.5 & 6 & 2 & $33 \pm 11.55^{\star} \mathrm{a}$ \\
\hline 5 & 6 & 3 & \\
\hline
\end{tabular}

Asterisks show the significant difference $(P<0.05)$ between the groups of mice that received the anti-tryps serum and the reference drug. Letters show the significant difference $(P<0.05)$ between the groups of mice that received the anti-tryps serum.
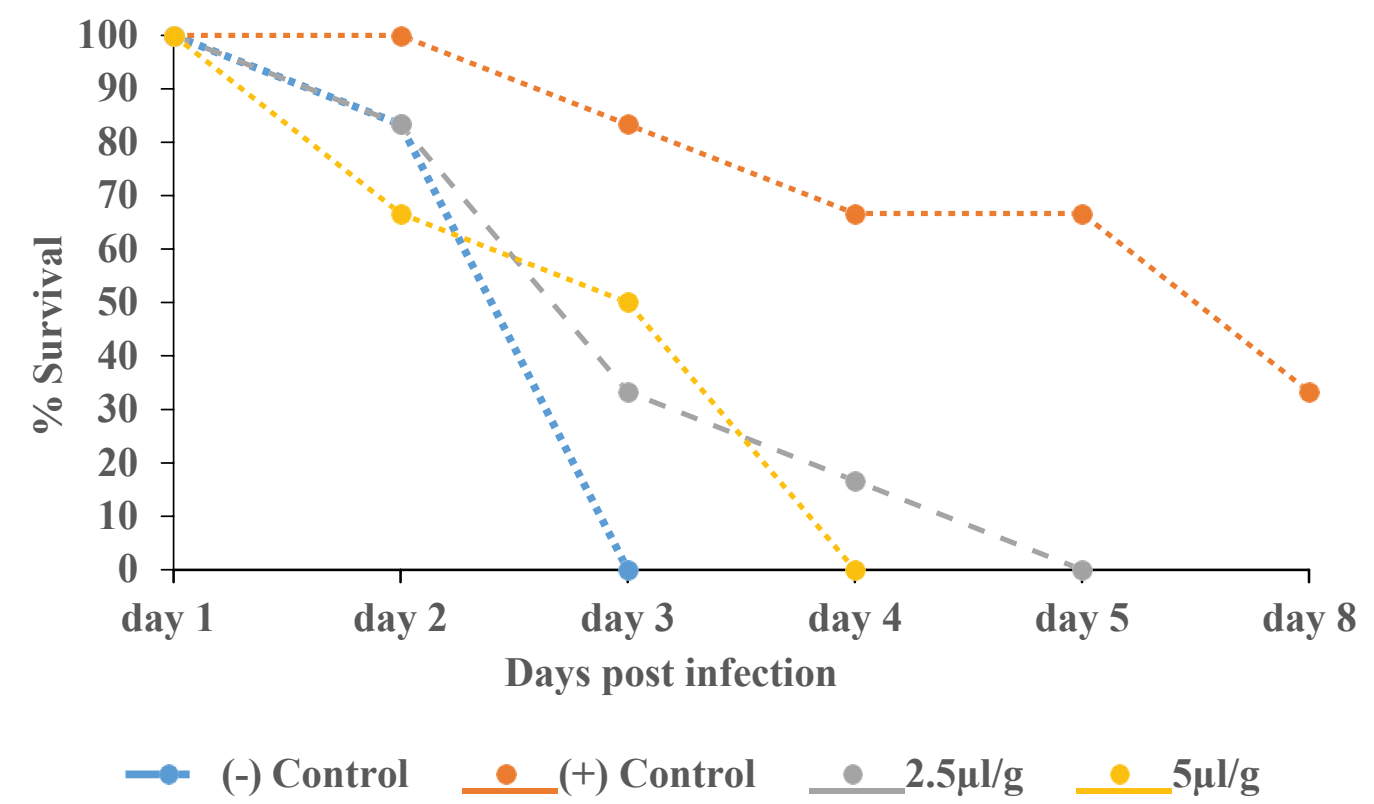

Figure 2: Mortality of mice pre-treated ip with anti-tryps polyclonal serum after infection with Trypanosoma congolense. 
Table 6: Behavior of $T$. congolense-infected mice after in preventive treatment with anti- tryps polyclonal serum, free anti-tryps serum and diminazene aceturate.

\begin{tabular}{|c|c|c|c|c|}
\hline \multicolumn{3}{|c|}{$\begin{array}{l}\text { Anti-tryps polyclonal serum } \\
(\mu \mathrm{l} / \mathrm{g} \text { bw) }\end{array}$} & \multirow[t]{2}{*}{$\begin{array}{l}\text { Free Anti- tryps } \\
(5 \mu \mathrm{l} / \mathrm{g} \text { bw) }\end{array}$} & \multirow[t]{2}{*}{$\begin{array}{l}\text { Drug } \\
(10 \mathrm{mg} / \mathrm{kg} \mathrm{bw})\end{array}$} \\
\hline & 5 & 2.5 & & \\
\hline Day 1 & $\begin{array}{ll}\text { - } & 5 \text { alive } \\
\text { - } & \text { Weak } \\
\text { - } & \text { Eating }\end{array}$ & $\begin{array}{ll}\text { - } & 6 \text { alive } \\
\text { - } & \text { Weak } \\
\text { - } & \text { Eating }\end{array}$ & $\begin{array}{ll}\text { - } & 6 \text { alive } \\
\text { - } & \text { Weak } \\
\text { - } & \text { not eating }\end{array}$ & $\begin{array}{ll}\text { - } & 6 \text { alive } \\
\text { - } & \text { Weak } \\
\text { - } & \text { not eating }\end{array}$ \\
\hline Day 2 & $\begin{array}{ll}\text { - } & 5 \text { alive } \\
\text { - } & \text { Weak } \\
\text { - } & \text { Eating }\end{array}$ & $\begin{array}{l}\text { - } \quad 5 \text { alive } \\
\text { - } \quad \text { Weak } \\
\text { - } \quad 1 \text { not eating }\end{array}$ & $\begin{array}{ll}\text { - } & 3 \text { alive } \\
\text { - } & \text { Very weak } \\
\text { - } & \text { Not eating } \\
\text { - } & \text { Not moving } \\
\text { - } & \text { All dead }\end{array}$ & $\begin{array}{ll}\text { - } & 4 \text { alive } \\
\text { - } & \text { Weak } \\
\text { - } & \text { Eating }\end{array}$ \\
\hline Day 3 & $\begin{array}{ll}\text { - } & 4 \text { alive } \\
\text { - } & \text { Weak } \\
\text { - } & \text { Eating }\end{array}$ & $\begin{array}{ll}\text { - } & 4 \text { alive } \\
\text { - } & \text { Weak } \\
\text { - } & \text { Eating }\end{array}$ & & $\begin{array}{ll}\text { - } & 2 \text { alive } \\
\text { - } & \text { Very weak } \\
\text { - } & \text { No eating }\end{array}$ \\
\hline Day 4 & $\begin{array}{ll}\text { - } & 4 \text { alive } \\
\text { - } & \text { Weak } \\
\text { - } & \text { Eating }\end{array}$ & $\begin{array}{ll}\text { - } & 4 \text { alive } \\
\text { - } & \text { Weak } \\
\text { - } & \text { Eating }\end{array}$ & & All dead \\
\hline Day 5 & $\begin{array}{ll}\text { - } & 5 \text { alive } \\
\text { - } & \text { Weak } \\
\text { - } & \text { Eating }\end{array}$ & $\begin{array}{ll}\text { - } & 3 \text { alive } \\
\text { - } & \text { Weak } \\
\text { - } & \text { Eating }\end{array}$ & & \\
\hline Day 7 & $\begin{array}{ll}\text { - } & 2 \text { alive } \\
\text { - } & \text { Very weak } \\
\text { - } & \text { Not eating }\end{array}$ & $\begin{array}{ll}\text { - } & 3 \text { alive } \\
\text { - } & \text { Very weak } \\
\text { - } & \text { Not eating }\end{array}$ & & \\
\hline
\end{tabular}

Table 7: Parasitemia of $T$. congolense isolates during the experimental infection in mice.

\begin{tabular}{|c|c|c|c|}
\hline Treatment & $\begin{array}{c}\text { Number of mice } \\
\text { tested }\end{array}$ & $\begin{array}{c}\text { Number of animal } \\
\text { resistant }\end{array}$ & $\begin{array}{l}\text { Average parasitemia } \\
\text { (Parasites } / \mathrm{ml} \text { blood) }\end{array}$ \\
\hline Normal serum & 6 & 5 & $33 \pm 11.55^{\mathrm{ns}}$ \\
\hline Reference drug & 6 & 5 & $35 \pm 19.15^{\mathrm{ns}}$ \\
\hline \multicolumn{4}{|c|}{ Anti-Tryps serum $(\mu \mathrm{l} / \mathrm{g}$ bw) } \\
\hline 2.5 & 6 & 4 & $8 \pm 17.89$ ns, a \\
\hline \multirow[t]{2}{*}{5} & 5 & 3 & $4 \pm 8.94$ \\
\hline & \multicolumn{2}{|l|}{$F=4.39 ; P=0.02$} & \\
\hline
\end{tabular}

Asterisks show the significant difference $(P<0.05)$ between the groups of mice that received the anti-tryps serum and the control group (Normal serum). Letters show the significant difference $(P<0.05)$ between the groups of mice that received the anti-tryps polyclonal serum.

infected with $T$. congolense after receiving anti-tryps polyclonal serum, free anti-tryps polyclonal serum and diminazene aceturate. Animals which received the anti-tryps polyclonal serum was stronger compared to those which received free anti-tryps serum. The positive control groups were more active and ate for more days compared to the negative control group. The animals in the anti-tryps group were very active for longer period and ate considerably compared to both control.

Preventive effect of anti-tryps serum on parasitemia of $\boldsymbol{T}$. congolense infection: Three days post infection, the parasitemia was determined in all survival animals. The result of examination is presented in Table 7. Compared to the parasitemia in animals that were treated with free Anti-Tryps serum, results showed that only Anti-Tryps polyclonal serum at $5 \mu \mathrm{l} / \mathrm{g}$ bw significantly lowered the parasitemia $(P=0.02)$.

Protective effect of anti-tryps serum on $T$. congolense infection on the survival of mice: Figure 3 displays the survival rate of animals after infection. On day 3 the survival of the animals in the negative control group was at zero percent. The survival in the positive control group was recorded zero percent on day 4 . The test groups ( 2.5 and $5 \mu \mathrm{l} / \mathrm{g}$ body weight) followed a similar decrease pattern in survival and both groups reached $0 \%$ survival on day 7 .

\section{Discussion}

The cattle examined for animal trypanosomosis in the present study were exposed to trypanosome trans- 


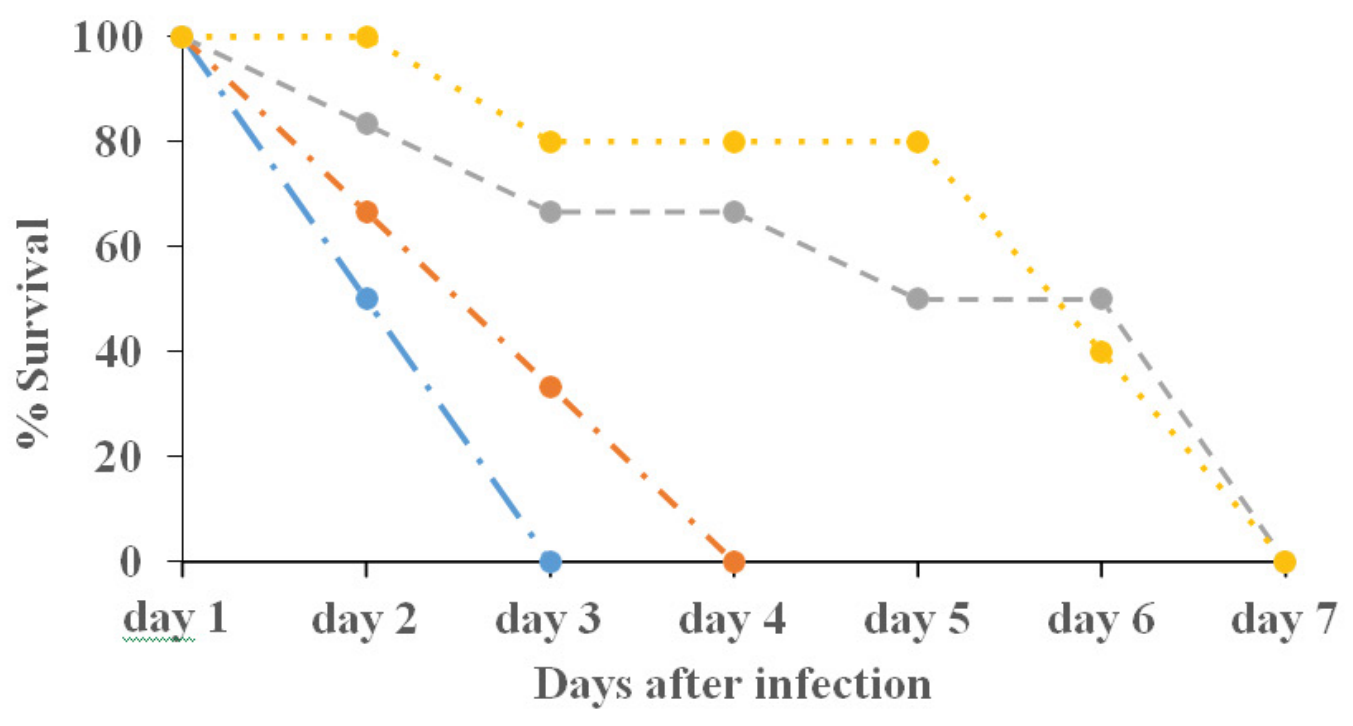

(-) Control (+) Control

$2.5 \mu \mathrm{l} / \mathrm{g}$

$5 \mu \mathrm{l} / \mathrm{g}$

Figure 3: Mortality of mice pretreated ip with anti-tryps serum before infection with Trypanosoma congolense.

mission risk for at least one month after receiving prophylactic doses of a trypanocide and had good BCS and no clinical signs of trypanosomosis. The overall prevalence of bovine trypanosomosis (4.03\%) in the study area is lower than that reported by Mamoudou, et al. $[2,3]$ in the same zone. The lower trypanosomosis prevalence in this study is simply the result of the discrimination of animals according to BCS. However, the present prevalence rate is higher than that observed by Dinsa, et al. [14] (2.20\%) and Mulaw, et al. [15] (1.8\%) among cattle of good BCS in Ethiopia. This may be due to the difference in the virulence of trypanosome strains.

In the present study, infections were largely dominated by $T$. congolense. Contrary observations were made by Ndamkou and Chare [1] in the North region and by Mpouam, et al. [16] in the Vina division, Adamawa region, Cameroon. This dominance of $T$. congolense may suggest an important immunotolerance of the strain resulting from low antigenicity or parasite mimicry.

Body condition scoring is a standardized method to estimate the amount of fat on an animal's body. The body condition score measures the balance between intake and expenditure of energy, and is known to be related to feeding motivation and health problems. A variety of factors including parasitic infections can be associated to the body condition [4]. In our study, the impact of trypanosome infection as an animal health indicator was found to be significant in cattle with good body condition score. The likelihood for an apparently healthy animal to be parasitologically free of trypanosome infection is significant in animal in good body condition score as reported by Mamoudou, et al. [3]. Animal of good body condition may maintain the parasitemia in low level without presenting the clinical signs. This may denote an increased immunotolerance of animal to the strain of trypanosome in circulation in the zone.
Animals have efficient immunity preventing the clinical stage of the disease [17]. Resistance to trypanosomiasis in some mammals such as the Cape Buffalo was linked to their capacity to mount an efficient anti-parasite antibody response [12]. Good body condition score may favour the development of a strong immunity.

Anaemia was found to be present in trypanosome infection in cattle of good BCS as reported by other studies without discrimination of animal [3]. Anaemia is a well-recognized and inevitable consequence of an infection with pathogenic trypanosomes [18]. This suggests that good BCS may not completely prevent the cattle from haematological complications if trypanosomes are present. Any factors compromising the immunity could result in clinical signs.

In this present study, it was found that serum of cattle infected with both $T c$ and $T v$ had a protective effect against $T$. congolense in mice. This suggests that good BCS of the animal result in development of immune elements present of serum controlling the overloading of parasites in animal. Umekita, et al. [19] had long cited the importance of antibodies in resistance against the acute phase of $T$. cruzi infection. Previously, it was demonstrated that antibodies with lytic ability are only efficiently induced after immunization with living parasites and react with living but not with dead parasites [20]. Therefore, this resistance of cattle when they are in good BCS may be due to the production of lytic antibodies.

In the other hand, the result of the present study demonstrated that immunization with anti-tryps polyclonal serum induced a strong humoral response and may partially protect the animals against a challenge trypanosome infection. These results contribute to a better understanding of protective anti- trypanosome immunity. 


\section{Conclusion}

In conclusion, carriers of trypanosomes are effectively present among cattle of good body condition score and this trypanosome infection result to anaemia. Their existence suggests that a resistant strain of trypanosomes may be circulating within the ranch and thus sustains the endemicity of the disease.

\section{Competing Interests}

The authors declare that they have no competing interests.

\section{Authors' Contributions}

Collected field data, helped in data analyses and wrote the paper: AJA. Revised the paper: EEJ. Conceived the study and wrote the paper: OM. Coordinated field work: FO. All authors read and approved the final version.

\section{Acknowledgment}

The authors are grateful to Abba Samuel, Coordinator of Mission Special d'Eradication des Glossines (MSEG) Ngaoundere, Cameroon and its staff for their technical, material support and for providing necessary facilities.

\section{References}

1. Ndamkou CN, Nchare A (1995) Bovine trypanosomosis in North Province of Cameroon. Laboratoire National Veterinaire de Bokle (LANAVET), Garoua, Cameroon.

2. Mamoudou A, Ebene NJ, Pierre FS, Mfopit MY (2015) Prevalence and impact of bovine trypanosomiasis in Mayo Rey division, a Soudano-Sahelian zone of Cameroon. Journal of Parasitology and Vector Biology 7: 80-88.

3. Mamoudou A, Njanloga A, Hayatou A, Suh FP, Achukwi MD (2016) Animal trypanosomosis in clinically healthy cattle of north Cameroon: Epidemiological implications. Parasit Vectors 9: 206.

4. Dan EE, Milyssa FB, John BH, Richard ED (2009) Body condition scoring beef cows. Produced by Communications and Marketing, College of Agriculture and Life Sciences. Virginia Polytechnic Institute and State University, 6.

5. Pruitt RJ (1994) Personal Communication. South Dakota State University, Brookings.

6. Ezanno P, Ickowicz A, Bocquier F (2003) Factors affecting the body condition score of N'dama cows under extensive range management in Southern Senegal. Anim Res 52: 3748.
7. NIH (1996) Guide for the care and use of laboratory animals. National Academies Press, Washington, DC.

8. Murray M, Trial TCM, Stephen LE (1983) Livestock productivity and trypanosomosis. ILCA, Addis Ababa, Ethiopia, 1-10.

9. Desquesnes M (2017) Recueil des protocoles standardisés des techniques de diagnostic des trypanosomoses animales d'origine africaine. Laboratoire de Référence de I'OIE sur les Trypanosomoses Animales d'Origine Africaine, 108.

10. MOARD (2005) Standard Veterinary diagnostic mannual. Parasitology, Volume III, Ministry of agriculture and rural development (MOARD), Addis Ababa, Ethiopia, 20-30.

11. Woo PTK (1970) The haematocrit centrifuge technique for the diagnosis of African trypanosomiasis. Acta Trop 27: 384-386.

12. Whiteside EF (1962) Interactions between drugs, trypanosomes and cattle in the field. In: Goodwin LG, Nimmo-Smith JRH, Churchill A, Drugs, Parasites and Hosts, 116-141.

13. Brener $Z$ (1969) The behaviour of slender and stout forms of Trypanosoma cruzi in the blood-stream of normal and immune mice. Ann Trop Med Parasitol 63: 215-220.

14. Dinsa B, Yohannes M, Degefu H, Woyesa M (2013) Cross-sectional study of bovine trypanosomosis and major clinical signs observed in Diga District, Western Ethiopia. African Journal of Agricultural Research 8: 500-506.

15. Mulaw S, Addis M, Fromsa A (2011) Study on the prevalence of major trypanosomes affecting bovine in tsetse infested Asosa District of Benishangul Gumuz Regional State, Western Ethiopia. Global Veterinaria 7: 330-336.

16. Mpouam SE, Achukwi MD, Feussom JM, Bengaly Z, Ouedraogo GA (2010) Serological and parasitological prevalence of bovine trypanosomiasis in small holder farms of the Vina division, Adamawa region of Cameroon. Veterinary Research 3: 81-88.

17. Black SJ, Sicard EL, Murphy N, Nolan D (2001) Innate and acquired control of trypanosome parasitaemia in Cape buffalo. Int J Parasitol 31: 562-565.

18. Murray M, Dexter TM (1988) Anaemia in bovine African trypanosomiasis: A review. Acta Trop 45: 389-432.

19. Umekita LF, Ramos DP, Mota I, (1997) Clearance-inducing antibodies are responsible for protection against the acute phase of Trypanosoma cruzi infection in mice. Braz J Med Biol Res 30: 1191-1197.

20. Umekita LF, Takerhara HA, Mota I (1988) Role of the antibody $\mathrm{Fc}$ in the immune clearance of Trypanosoma cruzi. Immunol Lett 17: 85-89. 